\title{
THE EFFECTIVENESS OF MULTICULTURAL APPROACH IN WRITING ACHIEVEMENT OF INDONESIAN LANGUAGE AMONG ELEMENTARY SCHOOL STUDENTS
}

\author{
Noor Alfulaila ${ }^{1 *}$, Haryadi ${ }^{2}$, Ajat Sudrajat ${ }^{2}$, Nashrullah \\ ${ }^{1}$ UIN Antasari Banjarmasin, Indonesia, ${ }^{2}$ Universitas Negeri Yogyakarta, Indonesia \\ *e-mail: nooralfulaila@uin-antasari.ac.id
}

\begin{abstract}
Multicultural approach in Indonesian language has become an absolute necessity over the last years. This research highlights the role of multicultural culture as a means to improve writing achievement of Indonesian Language among elementary school students. This study aims at determining the effectiveness of the multicultural approach in the writing achievement of Indonesian language among fifth grade students of islamic elementary school who are grouped based on their learning motivation. This study can be catagorized as an experimental study with $2 \times 2$ factorial design. The independent variable consists of two categories, multicultural and conventional approaches. The population was 60 fifth grade students of at two private islamic schools. The data was collected using learning achievement tests and learning motivation questionnaires, and analyzed using two-way ANOVA and sheffe test. The results showed that (1) there were a gap in learning achievement between students in the experimental group and control group students; (2) there were differences in learning achievement between students with high motivation between both groups; (3) there were differences in learning achievement between low motivated students between both groups; (4) the multicultural approaches proved to be more effective than the conventional one; and (5) there was no interaction between the approaches and the learning motivation.
\end{abstract}

Keywords: achievement, writing, multicultural approach, learning motivation

\section{KEEFEKTIFAN PENDEKATAN MULTIKULTURAL TERHADAP PESTASI BELAJAR MENULIS BAHASA INDONESIA SISWA SEKOLAH DASAR}

\begin{abstract}
Abstrak: Pentingnya pendekatan multikultural dalam pembelajaran Bahasa Indonesia pada saat ini sangat mutlak. Penelitian ini menggaris bawahi peran pendekatan multikultural sebagai sarana untuk meningkatkan prestasi belajar menulis bahasa Indonesia siswa sekolah dasar. Penelitian ini bertujuan untuk mengetahui pengaruh pendekatan multikultural terhadap prestasi belajar menulis bahasa Indonesia pada siswa yang dikelompokkan berdasarkan motivasi belajar. Penelitian ini merupakan penelitian ekperimen dengan desain $2 \times 2$ faktorial. Variabel bebas memiliki dua level, yaitu pendekatan multikultural dan pendekatan konvensional. Populasi terdiri dari 60 siswa kelas lima pada dua sekolah islam swasta. Data dikumpulkan menggunakan tes prestasi belajar dan angket motivasi belajar, dan dianalisis dengan menggunakan Anova dua jalur dan uji sheffe. Hasil penelitian menunjukkan bahwa (1) terdapat perbedaan prestasi belajar antara siswa pada kedua kelompok; (2) terdapat perbedaan prestasi belajar antara siswa dengan motivasi tinggi pada kedua kelompok; (3) terdapat perbedaan prestasi belajar antara siswa bermotivasi rendah pada kelompok ekperimen dengan siswa yang berada di kelompok kontrol; (4) pendekatan multikultural terbukti lebih efektif daripada pendekatan konvesional; dan (5) tidak terdapat interaksi antara pendekatan dengan motivasi belajar.
\end{abstract}

Kata Kunci: prestasi belajar, menulis, pendekatan multikultural, motivasi belajar

\section{INTRODUCTION}

Educational process can be done anytime and anywhere. Many experts even explain that humans need education since they were born until their entire life. It also has become a main asset for human to be better than others. For Indonesia context, education is inevitable from the urgency of multicultural values. It makes multicultural education crucial to be applied at every level of education (from elementary to higher education) 
and it actually has been implemented by several schools. The idea and practice of multicultural education in primary schools, especially Islamic primary schools (Madrasah Ibtidaiyah/ MI) become the main focus of this research. Multicultural education is a form of educational reform that aims to provide equal opportunities for students regardless of their background so that all students can improve their abilities to the optimal level according to their interests and talents (Zamroni, 2011).

As stated by Yaqin (2005), the habit formation in the process of multiculturalis very important from elementary school age until adulthood to make them understand that the surrounding environment has a lot of diversity. The lack of understanding on multicultural education can cause various problems like conflict and clash, such as in Poso, Sampit, Surabaya terror, and other problems due to the diversity of Indonesia.

The potential material to emphasize multicultural values is Indonesian language where it should be carried out with student-centered approach. It should be oriented to students' needs for communication means that can be used to express all thoughts and feelings about identity, community and natural surroundings as well as emphasize on their socio-cultural needs (Zuchdi \& Budiasih, 1997).

Based on the initial observations results, writing learning at Al-Hamid Islamic School and State Islamic Primary School of Pemurus Dalam has not received special attention from the classroom teacher. The teacher spend the biggest portion of teaching with the lecture method without any approach and learning media. The interviews section with students revealed that the students felt bored and lack of interest in their writing lessons and the learning process is considered difficult and less attractive to students. This fact is supported by the results of the writing test conducted on 2017, which from 14 classes of fifth grade students, 10 students obtained the score below 75 , and the mean score was only 55.

Learning Indonesian language should be supported by the appropriate media and the approach. However, the applied media and approaches in the classroom are not in line with the government's targets, especially the integrated Indonesian language material. In case of media, the teachers usually use textbooks and modules containing paragraphs withsome explanations which tend to make students bored and less motivated. Moreover, the assumption of writing as a difficult and boring lesson as well as the use of traditional approaches or methods can decrease the student interest to write. In fact, the initial requirement to form motivation is the interest. A similar idea expressed by Arigiyati (2011) that someone who has great motivation will show interest, attention, concentration, high perseverance, and achievement-oriented without boredom, and giving up. Students who have high learning motivation can find it easier to follow the learning process because they feel that learning is important,on the other hand, low motivation students seem unhappy so they have difficulty to understand the concepts and the learning processes. In this circumstance, multicultural approach in classroom learning is really needed to raise the students' interest and motivation.

As stated by Howe \& Lisi (2014), multicultural education is a pedagogical approach that teaches students to respect and live with diversity. Teachers' efforts in promoting understanding and sensitivity in classrooms as well as culturally relevant involving: (1) contribution approaches; (2) additive approach; (3) transformation approach; (4) social action approach. In addition to these four approaches. Nieto (2010) emphasizes that there are other supporting aspects in multicultural education, namely tolerance, acceptance, respect, and affirmation, solidarity, and criticism. The core values of multicultural education are democratization, humanism and pluralism. The value of democratization or justice is a comprehensive term in all forms, both cultural, political and social justice. Meanwhile, the value of humanism is basically an acknowledgment of plurality, heterogeneity, and human diversity. Finally, the value of pluralism, namely the view that recognizes the diversity in a nation. Multicultural education is a process of comprehensive school reform and basic education for all students. It challenges and rejects racism and other forms of discrimination in school and society and accepts and affirms the pluralism (etnic, racial, linguistic, religious, economic, and gender, among others) that reflect students, their communities, and teachers. 
The population of this study was all students in fifth grade of seven Islamic elementary schools in Banjarmasin. The sampling was done randomly by considering the students'diversity of their ethnicity, religion, parent's educational background, and gender. The following stages were done successively. They were (1) determining two schools as the research setting; (2) determining both schools randomly to be the experimental and the control group; (3) grouping the students based on their level of learning motivation through questionnaire before the treatment; (4) sorting the results of the learning motivation questionnaire of all students from the highest score to the lowest; and (5) determining the upper group of students as highly motivated students and lower group students as low motivated group of students. The number of samples used in each stage according to the study design were 60 students. Procedure of the multicultural based learning activity can be seen in Appendix A.

The following Table 2, describes the number of upper and lower group samples based on these provisions.

Data analysis was performed to test the hypotheses and to determine its effectiveness by using the Scheffe test. The data collection consisted of two types, data on learning motivation and achievement of writing among the fifth grade students in the first semester of Islamic elementary school in the academic year of 2017/2018. The data on student learning achievement were collected by a test developed by the researchers. The number of items was 30 , with a reliability coefficient of .825 and the learning motivation questionnaire used a Likert scale of 12 items with a reliability coefficient of .786 .

The escalation of learning achievement in Indonesian language writing was analyzed through the distribution of frequency by using interval. The following Table 3, describes the criteria for learning outcome of writing.

\section{Table 3. Criteria for Learning Outcome}

Based on the table above, it can be seen that students writing ability taught by using conventional approach included into three categories of four defined categories, namely very high, high, and low category. Students who are included in the very high category are 9 people or $31.1 \%$ and with high category are 20 students or $66.6 \%$ while students who are in the low category is 1 person or $3.3 \%$. Thus, it can be concluded that the writing ability of control group students tends to be in the high category. Furthermore, it can also be seen that the writing ability of students taught by using Multicultural approach included into two categories of four defined categories, namely very high categories and high categories. Students who entered the high category were 20 students or $64.5 \%$ and students who entered the high category were 11 students or $33.5 \%$. Thus, it can be concluded that the writing ability of the experimental group students tends to be in a very high category.

Tabel 2. Group Category

\begin{tabular}{crccc}
\hline No. & School & High Motivation & Low Motivation & Number \\
\hline 1. & Private School 1 & 14 & 16 & 30 \\
2. & Private School 2 & 16 & 14 & 30 \\
\hline
\end{tabular}

Table 3. Criteria for Learning Outcome

\begin{tabular}{|c|c|c|c|c|c|}
\hline \multirow{2}{*}{ Criteria } & \multirow{2}{*}{ Kategori } & \multicolumn{2}{|c|}{ Control Group } & \multicolumn{2}{|c|}{ Experiment Group } \\
\hline & & Frequency & Percentage & Frequency & Percentage \\
\hline Score $>\mathrm{Mi}+1.5 \mathrm{Sdi}$ & $\begin{array}{c}\text { Very high } \\
(\text { score } 23-30)\end{array}$ & 9 & $30.1 \%$ & 20 & $64.5 \%$ \\
\hline $\mathrm{Mi}<\mathrm{Score} \leq \mathrm{Mi}+1.5 \mathrm{Sdi}$ & $\begin{array}{c}\text { High } \\
(\text { score } 15-22)\end{array}$ & 20 & $66.6 \%$ & 11 & $33.5 \%$ \\
\hline $\mathrm{Mi}-1.5 \mathrm{Sdi}<\mathrm{Score} \leq \mathrm{Mi}$ & $\begin{array}{c}\text { Low } \\
\text { (skor } 8-14)\end{array}$ & 1 & $3.3 \%$ & 0 & $0 \%$ \\
\hline Score $\leq \mathrm{Mi}-1.5 \mathrm{Sdi}$ & $\begin{array}{c}\text { Very low } \\
(\text { score } 0-7)\end{array}$ & 0 & $0 \%$ & 0 & $0 \%$ \\
\hline
\end{tabular}


The normality of the data was tested using the Kolmogorov Smirnov (K-S) test, while the variance homogeneity was tested using the $\mathrm{F}$ test or lavene test. Meanwhile, the research hypothesis was tested using the two-way analysis of variance (ANAVA) technique. Researcher used Analisis MicroCAT system with ITEMAN 3.00 version and also used correlation technique of point biserial. Questionnaire for students learning motivation was analyzed by using SPSS version 15.00 for windows.

\section{RESULTS AND DISCUSSION Results}

The results of hypothesis testing through two-way analysis of variance can be summarized in Table 4.

Based on the results of the analysis of two-lane variants, the calculation of $F_{c v}$ is 2.213 with the probability of error .142. If the $F_{c v}$ is confirmed to $F_{o b s}$ with a significance level of .05 $(5 \%)$ where $\mathrm{db} 1$ is for the numerator and 57 for the denominator, the number 4.012 is obtained on $\mathrm{F}_{\mathrm{obs}}$ which means $F_{c v}$ is smaller than $F_{o b s}$. Since the probability of error is greater than the significance level set at .05, $\mathrm{HO}$ is accepted and $\mathrm{Hl}$ is rejected, so it can be concluded that there is no significant interaction between multicultural learning approaches and student motivation in influencing student learning outcomes.

To find out the higher and effective approach, it can be done using the Scheffe test. The results of the test can be seen as follows.
After obtaining a significant FA and FB score, the Scheffe test was used to see the differences between cells. Through this Scheffe test it will be seen whether there are significant differences in writing learning outcomes between students taught through the Multicultural approach $\left(\mathrm{A}_{1} \mathrm{~B}_{1}\right)$ and students taught through conventional approaches $\left(\mathrm{A}_{2} \mathrm{~B}_{1}\right)$ in the group of students who have low motivation.

From the calculation results obtained $F_{c v}$ of 2.506 while $F_{o b s}$ at the $5 \%$ significance level with $\mathrm{db} 1=1$, and $\mathrm{db} 2=57$ obtained a value of 2.000 and 2.660 for a significance level of $1 \%$. This means $t_{\text {count }}>t_{\text {table }}$ for the significance level of 5\%. Therefore, $H O$ is rejected and $H 1$ is accepted. Thus, it can be concluded that there are significant differences in writing learning outcomes between highly motivated students taught through multicultural approaches and students taught through conventional approaches. For more details, the results of the calculation of the Scheffe test can be summarized as in Table 6 below.

Based on analysis result above, the mean score for groups of low motivated students taught through Multicultural approach (A1B2) that is = 21.76 and the mean for low motivated students taught through conventional approaches (A2B2) is $=19.00$, its mean that learning outcomes of writing between students those taught through the Multicultural approach are higher than students who are taught through conventional approaches in groups of students who are low motivated and the difference is significant. This

Table 4. The Summary of Two-Way Analysis of Variance (ANAVA)

\begin{tabular}{ccccccc}
\hline Variance source & Number of Quadrate & $\mathbf{d b}$ & $\begin{array}{c}\text { Mean of } \\
\text { Quadrate }\end{array}$ & $\mathbf{F}_{\text {count }}$ & $\mathbf{F}_{\text {table 0.05 }}$ & $\begin{array}{c}\text { Probability of } \\
\text { error }\end{array}$ \\
\hline Approach (A) & 198.302 & 1 & 198.302 & 21.293 & 4.012 & .000 \\
Motivation (B) & 287.069 & 1 & 287.069 & 30.824 & 4.012 & .000 \\
$\begin{array}{l}\text { Approach * } \\
\text { Motivation }\end{array}$ & 20.612 & 1 & 20.612 & 2.213 & 4.012 & .142 \\
$\begin{array}{l}\text { Probability } \\
\text { Error (D) } \\
\quad \text { Total }\end{array}$ & 530.853 & 57 & 9.313 & - & & \\
Total of Reduction & 32062.000 & 60 & - & & & \\
\hline R square $=.481($ adjusted R Squared $=.454)$ & 60 & - & & & &
\end{tabular}

Table 5. Scheffe Test Result

\begin{tabular}{ccccc}
\hline No. & Comparison of mean group & $\mathbf{T}_{\text {count }}$ & $\mathbf{t}_{\text {table }}$ & Explanation \\
\hline 1. & $\mathrm{~A}_{1}$ and $\mathrm{A}_{2}$ & 4.48 & 2.00 & $\mathrm{t}_{\text {count }} \mathrm{t}_{\text {table }}$ \\
2. & $\mathrm{~A}_{1} \mathrm{~B}_{1}$ and $\mathrm{A}_{2} \mathrm{~B}_{1}$ & 4.40 & 2.00 & $\mathrm{t}_{\text {count }} \mathrm{t}_{\text {table }}$ \\
3. & $\mathrm{~A}_{1} \mathrm{~B}_{2}$ and $\mathrm{A}_{2} \mathrm{~B}_{2}$ & 2.50 & 2.00 & $\mathrm{t}_{\text {count }} \mathrm{t}_{\text {table }}$ \\
\hline
\end{tabular}


Table 6. Scheffe Test Result of Learning Outcomes Students Writing with Low Motivation Experiments and Control Groups

\begin{tabular}{ccccccc}
\hline Learning Approach & \multirow{2}{*}{ Multicultural } & \multirow{2}{*}{ Conventional } & \multicolumn{3}{c}{$\mathbf{t}_{\text {table }}$} \\
\cline { 5 - 7 } & & & $\mathbf{t}_{\text {count }}$ & $\mathbf{. 0 5}$ & $\mathbf{. 0 1}$ \\
\hline Mean & 21.76 & 19.00 & & & \\
Mean Square & & 9.313 & & 2.506 & 2.000 & 2.660 \\
DF & & 57 & & & & \\
\hline
\end{tabular}

is evidenced by the acquisition of the Scheffe test results which means that the Multicultural approach is effective to improve the learning outcomes of low motivated students.

\section{Discussion}

Based on the results of the analysis above, it can be seen that there was no effect of the interaction between the learning approach and student learning motivation. Thus, the multicultural approach can be applied to any student's level of motivation. The use of multicultural approach by giving example and current isssues relate it to everyday life could develop good value from diverse culture within the student which could be practices in daily lives. This approach provide awareness to students about the importance of unity in life and avoid doing things that could cause separating among students. This is explained by the following interview. The use of student centred strategies in implementing language teaching, and the usage of question and answer method asks students about the needs of the diverse cultures such as avoiding conflict among students and the concept of unity (Omar, Noh, Hamzah, \& Majid, 2015). This method is also used on students with lower motivation.

Firstly, the research hypothesis stating that the learning achievement of writing students with the multicultural approach is higher than students with conventional approaches can be proven based on the data. According to the learning achievements, the multicultural approach is effective to measure low, medium and high cognitive abilities. Related to the characteristics of students' writing, such as activities of understanding, accepting, rejecting, comparing as well as believing the opinions in writing. Those characteristics are in accordance with the nature of the multicultural approach, i.e. accepting diversity. This is in line with the current study extends by Yampolsky \& Amiot (2016) beyond an examination of discrimination's relationship to a single identity to focus on how discrimination predicts the very relationship between one's identities, and how one configures these identities within the self in response to the experience of discrimination.

The facts that support the above reasons were the achievement of the mean learning achievement of writing with the multicultural approach was higher than the students who were taught with conventional approaches. It was empirical evidence that treatment through multiculturalism was more effective in improving students achievement in experimental groups than the control group. Therefore, it has been proven that multicultural approach also effective for writing skill beside the research finding of Sofeny (2019) that stated the technique of mind mapping, flow charting, and double/ triple Entry are three of the many writing techniques that can be used in improving writing skills.

Thus, the stated hypothesis is proven to be true. Learning through a multicultural approach continuously can improve the students learning achievement compared to the conventional approach. The findings above are supported by the opinions from the experts who state that the results as part of the analysis of cognitive effects on writing learning that have been investigated in various studies (Pajares, 2003). The simple actions of writing will enhance new learning both at the conceptual and linguistic level. There is a difference between writing from a particular theme with writing as a process of finding, where understanding and mastering concepts are closely related to the interaction between themes and aspects of rhetoric (the relationship between themes, purpose of writing, gender, age and target audience). The students' awareness on the importance of writing strategies not only increases verbal abilities but also achievements in learning (Pajares, 2007). 
Secondly, the research hypothesis stating that learning achievement between the high learning motivation students who are given multicultural treatment is higher than conventional group students can be empirically proven by the data. The characteristics of high learning motivation were in accordance with the multicultural approach, namely students critical thinking and creativity, cooperation, striving to achieve better learning standards, and creating meaningful relationships. It is clearly in line with the findings of the present study (Zorn, Dillenseger, Bauer, Moerschel, Bachmann, Buissink, \& Jamault, 2018) that defining motivation was not easy. The trainer or teacher used various strategies to motivate students, not all of which were verbalized in interviews. Although students said they were stresses prior to participating in role-play simulation, but that such simulation session are effective to develop high motivational dynamics for students. The areas of improvement were exploring students' expectation, give importance briefing so that the students can fully perform their role and improving the authenticity of the environment.

The most important thing is that the multicultural approach can provide a richer feedback value for students which in turn will improve the optimal quality of student learning. The multicultural approach provides freedom in expressing ideas and thoughts to encourage students to express their opinions confidently so they can enhance the learning quality. The freedom to express themselves in case of opinions can increase the students' learning motivation, as an important factor in the learning process that reflected in the applicable curriculum.

Based on the results of Saliman \& Mukminan research (2014), multicultural education is integrated into all subjects because the curriculum is one aspect of multicultural education which plays an important role in directing teachers to educate students in the classroom. Thus, the multicultural education model can be run more systematically and structured.

The fact that supporting the above statement shows that the mean score of learning achievementamong students who havemotivation to learn and taught through the multicultural approach is higher than those who are learned through the conventional approaches. It is in line with the characteristics of the multicultural approach with high motivational characteristics. Therefore, the high learning motivation students taught with the multicultural approach gain higher learning achievement compared to the students with conventional approaches.

Thirdly, the research hypothesis stating that students' learning achievement between low learning motivation students who are given multicultural treatment is higher than students with conventional treatment can be proven in the field tested by the data. The characteristics of low learning motivation are very dependent on external motivation and lack of initiative in learning, they tend to prefer learning programs that have been structured and follow learning programs whose goals have been clearly formulated. They are also very dependent on the teacher while, in multicultural approaches, it encourages the students to organize ideas, judge, make conclusions and explain cause and effect. Thus, the multicultural approach facilitate students who have low learning motivation to actively participate in the learning process to increase their motivation and learning performance, which subsequently improve their optimal learning achievement.

The fact supporting the above statement suggests that the achievement of the mean score of learning achievement among low learning motivation students which are taught with multicultural approach is higher than students who are treated with the conventional approaches. Thus, the students who have low learning motivation taught through a multicultural approach gain higher learning achievement than students with conventional approaches.

Fourthly, the research hypothesis stating that there is an interaction between the learning approach and learning motivation towards student achievement cannot be proven empirically by the data. It means the multicultural approach can be applied to all groups, both of highly motivated groups and low motivated groups. So, it can be concluded that the effectiveness of the multicultural approach does not depend on the level of the student motivation towards the results of Indonesian language writing.

The results of this study are also supported by Siswandari's (2014) which illustrates that learning in schools can be a crucial aspect for multiculturalism. Therefore, learning Indonesian 
language and literature should be relevant to the context of society. Teachers and students can utilize a variety of materials that are relevant to the context of multicultural life as well as developing critical thinking to have meaningful learning. In addition, it is suggested that in the learning of short story and poetry appreciation, the teacher should choose a multicultural theme to encourage students to be wise in addressing differences.

The results of the analysis show that there is no interaction between the learning approach and learning motivation, but throughmulticultural approach,the students become more confident to express opinions or ideas differently from their friends even their teachers. The motivation to make sense of complex categories to which one might belong (Kang \& Bodenhausen, 2015) might facilitate both student achievement and learning approach. The stimulus from the teacher can be also some indicator of the student learning motivation. Discussion Multicultural education proposes that cultural identity is an important bridge between learning and student development. The development of ethnic or racial identity, enhanced by participation in multicultural schooling, allows studentsto internalize multicultural values and to prepare to use them in action (Nagda, Kim, \& Truelove, 2004).

Discussion multicultural education is in the form of motivational treatment, by giving praise to students. In completing assignments, the students work together with their groups so that they get different experiences from his/her group members. In other words, the multicultural approach provides a learning environment that allows students to express themselves, respect other opinions and give students the opportunity to find and discover their own knowledge though they are different from one another.

It is in line with the results of Atamimi research (2015) which found that applying counseling in elementary schools require qualified psychological skills, because of the diversity or multi-ethnicity in elementary school students and their different characteristics. It is similarly showed that motivation is assumed as a central concept in the process of self regulated, which depends on: knowledge about the motivational process and the student's ability to mobilize and monitor strategies to increase, maintain or modify their own motivation (Wolters, 2011; Paulio \& da Silva, 2011). Recent studies show that students report the use of motivational regulation strategies which is associated with self efficacy beliefs, task and achievement goals (Wolters \& Rosenthal, 2000; Tavakolizadeh, Ebrahimi-Qavam, Farrokhi, \& Golzari, 2011).

\section{CONCLUSION}

Based on the results of the hypothesis testing and the discussion, some conclusion can be drawn related to the learning process of writing among fifth grade students of elementary school for Indonesian language subject: (1) there were a gap in learning achievement between students in the experimental group and control group students; (2) there were differences in learning achievement between students with high motivation in the experimental group and the students of the control group; (3) there were differences in learning achievement between low motivated students in the experimental group and students of the control group; (4) the multicultural approaches proved to be more effective than the conventional one; and (5) there was no interaction between the approaches and the learning motivation (interaction $\mathrm{AxB}$ ). Accordingly, it can be suggested that writing instruction may be varied using the multicultural approach regardless the motivation level. Future research may be done to explore more factors contributing to the effectiveness of the approach.

\section{ACKNOWLEDGEMENT}

Greatest appreciation and thank come to principals, vice principals, teachers, and students for their support, information, and collaboration for making this research is done. This research was supported by Indonesia Endowment Fund for Education (LPDP).

\section{REFFERENCES}

Atamimi, N. (2015). Keterampilan psikologis model bimbingan konseling proaktif untuk guru sekolah dasar. Cakrawala Pendidikan, 34(3), 421-433. doi:10.21831/ cp.v3i3.7358.

Arigiyati, T. A. (2011). Pengaruh kedisiplinan, motivasi belajar, dan dukungan orang tua terhadap prestasi belajar mata kuliah 
metode statistika mahasiswa Program Studi Pendidikan Matematika angkatan 2009. Jurnal Wacana Akademika, 3(9), 922-931.

Bowman, N. A. (2012). Promoting sustained engagement with diversity: The reciprocal relationships between formal and informal college diversity experiences. Review of Higher Education, 36(1), 1-24. doi:10.1353/rhe.2012.0057.

Bowman, N. A. (2009). College diversity courses and cognitive development among students from privileged and marginalized groups. Journal of Diversity in Higher Education, 2(3), 182-194. doi:10.1037/a0016639.

Howe, W. A., \& Lisi, P. L. (2014). Becoming a multicultural educator: Development awareness, gaining skills and taking action. California, CA: Sage.

Kang, S. K., \& Bodenhausen, G. V. (2015). Multiple identities in social perception and interaction: Challenges and opportunities. Annual Review of Psychology, 66(1), 547-574. doi:10.1146/annurev-psych010814-015025.

Mulune, T. K. (2018). Improving students' paragraph writing skill trough task based approach. Art and Social Sciences Journal, 9(351), 1-4. doi:10.4172/21516200.1000351 .

Nagda, B. A., Kim, C., \& Truelove, Y. (2004). Learning about difference, learning with others, learning to transgress. Journal of SocialIssues, 60(1), 195-214. doi:10.1111/ j.0022-4537.2004.00106.x.

Nieto, S. (2010). Language, culture, and teaching: Critical perspective for a new century. New York, NY: Rouledge.

Omar, N., Noh, M.A. C., Hamzah, M. I., \& Majid, L. A. (2015). Multicultural education practice in Malaysia. Procedia - Sosial And Behavioral Sciences, 174(February), 1941-1948. doi:10.1016/j.sbspro.2015. 01.859 .
Pajares, F. (2003). Self-efficacy beliefs, motivation, and achievement in writing: A review of the literature. Reading and Writing Quarterly, 19(2), 139-158. doi:10.1080/10573560308222.

Pajares, F. (2007). Empirical properties of a scale to assess writing self-efficacy in school context. Measurement and Evaluation in Counseling and Development, 39(4), 239-249. doi:10.1080/07481756.2007.11909801.

Paulio, P., \& da Silva, A. L. (2011). Knowing how to learn and how to teach motivation: contributions from self-regulation of motivation to more effective learning. Procedia-Social and Behavioral Sciences, 29(2011), 656-662. doi:10.1016/j. sbspro.2011.11.289.

Prihantoro, P. (2015). Bahasa di balik pembunuhan karakter: Studi kasus rumor larangan hijab bagi pegawai BUMN. Litera, 14(2), 277-292. doi:10.21831/Ltr. V14i2.7204.

Saliman, W. T., \& Mukminan, M. (2014). Model pendidikan multikultural di Sekolah Pembauran Medan. Cakrawala Pendidikan,33(3),392-401. doi:10.21831/ cp.v3i3.2383.1

Siswandari, S. (2014). Pembelajaran Bahasa dan Sastra Indonesia di sekolah sebagai media perekat multikulturalisme. In Wiyatmi, Nurhadi, Kusmarwanti, A. Wahyudin, \&D. Budiyanto(Eds), Bahasa dan sastra dalam perspektif ekologi dan multikulturalisme (pp. 121-133). Yogyakarta: Interlude Fakultas Bahasa \& Sastra UNY.

Sofeny, D. (2019). Comparison of effectiveness of cluster mapping, flow charting, and double/ triple entry on teaching writing skill. Litera, 18(1), 92-104. doi:10.21831/ ltr.v18i1.21239.

Tavakolizadeh, J., Ebrahimi-Qavam, S., Farrokhi, N. A., \& Golzari, M. (2011). The effectuality of teaching of selfregulated learning strategies on mental 
health in students. Procedia - Social and Behavioral Sciences, 29(2011), 11051114. doi:10.1016/j.sbspro.2011.11.344.

Yampolsky, M. A., \& Amiot, C. E. (2016). Discrimination and multicultural identity configurations: The mediating role of stress. International Journal of Intercultural Relations, 55(2016), 86-96. doi: 10.1016/j.ijintrel.2016.09.002.

Wolters, C. A., \& Rosenthal, H. (2000). The relation between students' motivational beliefs and their use of motivational regulation strategies. Internasional Journal of Educational Research, 33(7-8), 801-820. doi:10.1016/s08830355(00)00051-3.

Wolters, C. A. (2011). Regulation of motivation: contextual and social aspects. Teacher's College Record, 113(2), 265-283.
Yaqin, A. (2005). Pendidikan multikultural: Cross-culture understanding untuk demokrasi dan keadilan. Yogyakarta: Pilar Media.

Zamroni, Z. (2011). Pendidikan demokrasi pada masyarakat multikultural. Yogyakarta: Gavin Kalam Utama.

Zorn, C., Dillenseger, J. P., Bauer, E., Moerschel, E., Bachmann, B., Buissink, C., \& Jamault, B. (2018). Motivation of student radiographers in learning situations based on role-play simulation: A multicentric approach involving trainers and students. Radiography, $\quad \operatorname{xxx}(2018), \quad 1-8 . \quad$ doi: 10.1016/j.radi.2018.09.002.

Zuchdi, D., \& Budiasih, B. (1997). Pendidikan Bahasa dan Sastra Indonesia di kelas rendah. Jakarta: Depdikbud. 
Appendix A

Summary of Multicultural Based Learning Procedures

\begin{tabular}{|c|c|c|c|}
\hline $\begin{array}{l}\text { Day } \\
\text { No. }\end{array}$ & Time allocation & Learning Topics & Learning activity in each topic \\
\hline 1 & $3 \times 35$ minutes & $\begin{array}{l}\text { Sub-theme } 1 \\
\text { Indonesiaku Bangsa yang Kaya } \\
\text { - Traditional Game } \\
\text { - Friendship \& Tolerance } \\
\text { - Appreciation for other culture }\end{array}$ & $\begin{array}{l}\text { (Preliminary) } \\
\text { - lead a prayer } \\
\text { - Deliver themes, sub-themes, indicators } \\
\text { and learning objectives } \\
\text { - Perform apperception through presenting } \\
\text { ME themes and initial questions }\end{array}$ \\
\hline 2 & $3 \times 35$ minutes & $\begin{array}{l}\text { Sub-theme } 2 \\
\text { Indonesiaku Bangsa yang } \\
\text { Berbudaya } \\
\text { - Traditional Game } \\
\text { - Sensitivity for Other Culture } \\
\text { (The Issue of Racism) } \\
\text { - Rion the Blind (The Issue of } \\
\text { Discrimination) }\end{array}$ & $\begin{array}{l}\text { (Core Activities) } \\
\text { (Knowledge) } \\
\text { - Provide students with instructions / } \\
\text { explanations about cultural diversity } \\
\text { - Guiding students to understand the } \\
\text { explanation given } \\
\text { (Awareness) } \\
\text { - Facilitating students to express the results } \\
\text { of understanding received } \\
\text { - Become a good and creative facilitator } \\
\text { (Skills/Action) } \\
\text { - Facilitating students to reflect learning } \\
\text { process } \\
\text { - Give students the opportunity to ask } \\
\text { questions \& opinions } \\
\text { - Give feedback }\end{array}$ \\
\hline 3 & $2 \times 35$ minutes & $\begin{array}{l}\text { Sub-theme } 3 \\
\text { Indonesiaku Bangsa yang Cinta } \\
\text { Damai } \\
\text { - Abe The Sea Son (The Issue } \\
\text { of Geography Experience) } \\
\text { - Poem (Good Literature of } \\
\quad \text { Multicultural) }\end{array}$ & $\begin{array}{l}\text { (Closing) } \\
\text { - Guiding students to conclude learning } \\
\text { - Provide opportunities for self-evaluation } \\
\text { - Appreciate all student achievements } \\
\text { - Providing advice regarding multicultural } \\
\text { values } \\
\text { - Welcome students to lead closing prayers } \\
\text { according to belief }\end{array}$ \\
\hline
\end{tabular}

